\title{
STUDY OF THE SIZE DIFFERENCE IN LASER-WELDING SPOTS OF ALUMINUM ALLOY
}

\author{
ŠTUDIJA VPLIVA RAZLIKE V VELIKOSTI VARILNIH TOČK NA \\ LASERSKO VARJENJE ALUMINIJEVE ZLITINE
}

\author{
Yanfeng Pan ${ }^{1,2 *}$, Yifu Shen ${ }^{1}$, Pizhi Zhao ${ }^{2}$ \\ ${ }^{1}$ College of Materials Science and Technology, Nanjing University of Aeronautics and Astronautics, Nanjing 210016, P. R. China \\ ${ }^{2}$ CHINALCO Materials Application Research Institute Co., Ltd. Suzhou Branch, Suzhou 215021, PR China
}

Prejem rokopisa - received: 2019-07-10; sprejem za objavo - accepted for publication: 2019-12-23

doi:10.17222/mit. 2019.146

\begin{abstract}
During laser spot welding of an Al-Fe alloy, there is a size difference in welding spots under the same sheet-surface condition and the same welding parameters. The microstructures of the surface of the Al-Fe alloy sheet before and after laser welding are analyzed by means of a light microscope (LM) and electron probe microanalysis. It is found that, compared with small welding spots, at the micro-zone where the welding spots are larger, the content of intermetallic compounds (IMCs) is higher before the welding and the contents of Fe and Mn, which constitute IMCs, are also higher after the welding. The results show that the distribution of IMCs in the sheet surface affects the size of laser-welding spots. The difference in the distribution of IMCs at the micro-zone of the sheet surface causes the difference in the size of the welding spots.

Keywords: laser spot welding, Al-Fe alloy, welding spot, intermetallic compound
\end{abstract}

Med laserskim točkovnim varjenjem (punktiranjem) pločevine iz Al-Fe zlitine, nastajajo različno velike varilne točke pri načeloma enaki vizualni površini pločevine in enakih parametrih varjenja. Zato so avtorji analizirali mikrostrukturo površine pločevine iz Al-Fe zlitine $\mathrm{z}$ optičnim mikroskopom (LM) in elektronskim mikro-analizatorjem vzorcev (EMPA). Analize so izvajali pred in po točkovnem laserskem varjenju. Ugotovili so, da v primerjavi z majhnimi varilnimi točkami večje nastajajo na mestih mikrocon, kjer je vsebnost intermetalnih spojin večja pred varjenjem in je vsebnost Fe in Mn, ki sestavljata intermetalne spojine, prav tako večja po varjenju. Rezultati analiz so avtorjem pokazali, da porazdelitev intermetalnih spojin na površini pločevine vpliva na velikost točk nastalih med laserskim varjenjem. Razlika v porazdelitvi intermetalnih spojin, v mikroconah na površini pločevine, povzroča nastanek različno velikih varilnih točk.

Ključne besede: lasersko točkovno varjenje, zlitina na osnovi Al-Fe, varilna točka, intermetalna spojina

\section{INTRODUCTION}

Due to excellent mechanical properties, corrosion resistance and formability, Al-Fe alloys become more popular in the application of many products, such as packaging, air-conditioning and vehicles and so forth. ${ }^{1-3}$ In recent years, Al-Fe alloys have been used for fabricating structural parts of lithium-ion batteries because of their good weldability and processability.

With the advantages of a high-speed, narrow weld seam, low distortion, small heat-affected zone and high degrees of precision and automation, ${ }^{4-6}$ laser welding has been widely used in many fields, such as aerospace ${ }^{6,7}$ and automobile transportation. ${ }^{4,8,9}$ Currently, aluminum-alloy structural parts of square lithium-ion batteries are mainly assembled by laser welding.

During the laser welding of aluminum alloys, various defects such as porosity, hot cracks and spatter are prone to occur. In addition, an abnormal weld pool of aluminum alloys may occur occasionally, which, however, has been studied less.
Some studies ${ }^{10-14}$ reported that the instability of the welding process caused abnormal weld pools, which was related to the metal vapor, plasma or the instability of the keyhole. It was also reported that the abnormality of a weld pool could be caused by the roughness, impurities or defects of the sheet surface..$^{15,16}$ The above researches mainly focused on a high laser power and deep penetration welding.

During the Nd:YAG low-power pulsed-laser welding of aluminum alloys, it was found that some aluminumalloy sheets are prone to abnormal weld pools, while others are not, which is difficult to explain in the light of the above studies. Laser welding of $\mathrm{Al}-0.85 \mathrm{Fe}$ and $\mathrm{Al}-1.35 \mathrm{Fe}$ aluminum alloys was reported in our previous work, ${ }^{2}$ which showed that IMCs of alloys could affect the laser-welding results. In this study, an attempt is made to further reveal the relationship between the size difference in weld pools and the distribution of IMCs during the laser welding of an $\mathrm{Al}-0.85 \mathrm{Fe}$ alloy sheet.

\section{MATERIALS AND METHODS}

Table 1 shows the chemical composition of the $\mathrm{Al}-0.85 \mathrm{Fe}$ alloy used in the present work. A direct-chill 
cast ingot was cold rolled to a $1.5-\mathrm{mm}$ thickness after the homogenization and hot rolling. Then the sheet used for laser welding was fully annealed at a temperature of $360{ }^{\circ} \mathrm{C}$ for $1 \mathrm{~h}$.

Table 1: Chemical composition of the alloy sheet (mass fractions)

\begin{tabular}{|c|c|c|c|c|}
\hline $\mathrm{Fe}$ & $\mathrm{Si}$ & $\mathrm{Mn}$ & $\mathrm{Ti}$ & $\mathrm{Al}$ \\
\hline 0.85 & 0.10 & 0.25 & 0.012 & Bal. \\
\hline
\end{tabular}

The microstructure of the sample sheet surface was observed with GX51 LM after grinding and mechanical polishing. Four groups of micro-zones with large differences in the content (the area fraction, the ratio of the area of IMCs to the zone area) of the IMCs were marked, respectively. Each group included two microzones, one had a high content of IMCs and the other had a low content of IMCs. The content of IMCs was measured for four groups.

Then spot welding was carried out for the four groups of micro-zones with a PB600 Nd:YAG pulsed laser with the maximum mean power of $600 \mathrm{~W}$. A sample was wiped with alcohol immediately prior to welding. High-purity argon (99.995\%) was used as the shielding gas. The laser-beam focus was on the sheet surface (the defocus was zero). The welding parameters are listed in Table 2. The laser-pulse shape was approximately a rectangle and the average welding output power was $246.5 \mathrm{~W}$.

Table 2: Pulsed-laser welding parameters

\begin{tabular}{|c|c|c|c|}
\hline $\begin{array}{c}\text { Peak } \\
\text { power }\end{array}$ & $\begin{array}{c}\text { Pulse } \\
\text { width }\end{array}$ & $\begin{array}{c}\text { Pulse } \\
\text { energy }\end{array}$ & $\begin{array}{c}\text { Pulse } \\
\text { frequency }\end{array}$ \\
\hline $5.8 \mathrm{~kW}$ & $4.5 \mathrm{~ms}$ & $24.65 \mathrm{~J}$ & $10 \mathrm{~Hz}$ \\
\hline
\end{tabular}
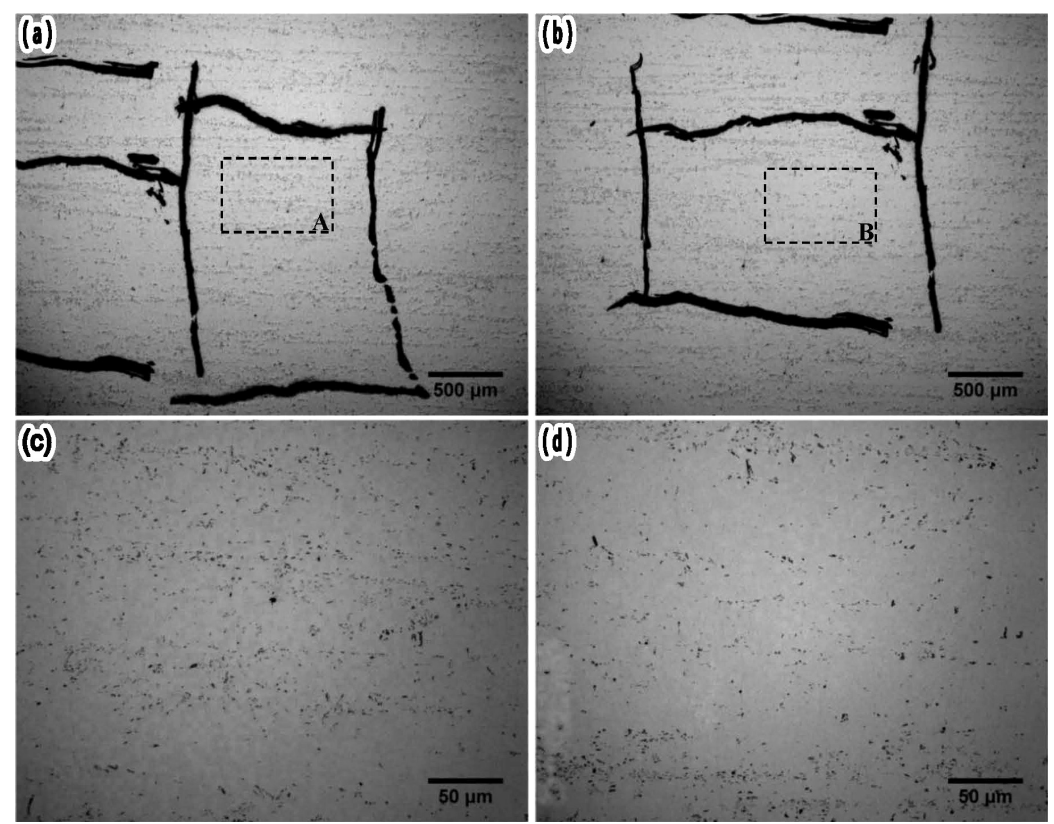

Figure 1: LM micrographs of the surface of the Al-0.85Fe alloy sheet: a) with a high content of IMCs, b) with a low content of IMCs, c) and d) high magnifications of micro-zones A1 and B1 from Figures 1a and 1b, respectively 


\subsection{Results of laser spot welding}

Laser spot welding was performed on the four groups of selected micro-zones with the welding parameters listed in Table 2 and the laser-beam spot was located at the center point of each micro-zone. Figure 2 shows the laser-welding spots. The widths of welding spots A1 and B1 were determined by measuring the surface diameters of the welding spots, whose average values were 1057 $\mu \mathrm{m}$ and $1008 \mu \mathrm{m}$, respectively.

Figure 3 shows the central cross-sections of welding spots $\mathrm{A} 1$ and $\mathrm{B} 1$. The weld penetrations of welding spots A1 and B1 were measured from the incident surface plane to the bottom of the weld pool, whose values were $638 \mu \mathrm{m}$ and $495 \mu \mathrm{m}$, respectively. Both welding spots were free from major defects such as cracks or porosity.

Table 3: Statistical results for IMCs, weld width and penetration

\begin{tabular}{|c|c|c|c|c|c|}
\hline \multicolumn{2}{|c|}{ Group } & $\begin{array}{c}\text { Content of } \\
\text { IMCs } / \%\end{array}$ & $\begin{array}{c}\text { Weld width } \\
/ \mu \mathrm{m}\end{array}$ & $\begin{array}{c}\text { Weld } \\
\text { penetration } \\
/ \mu \mathrm{m}\end{array}$ & $\begin{array}{c}\text { Aspect } \\
\text { ratio }\end{array}$ \\
\hline \multirow{2}{*}{ No.1 } & A1 & 2.7 & 1057 & 638 & 0.6 \\
\cline { 2 - 6 } & B1 & 1.4 & 1008 & 495 & 0.5 \\
\hline \multirow{2}{*}{ No.2 } & A2 & 2.9 & 1053 & 640 & 0.6 \\
\cline { 2 - 6 } & B2 & 1.6 & 1009 & 500 & 0.5 \\
\hline \multirow{2}{*}{ No.3 } & A3 & 2.8 & 1064 & - & - \\
\cline { 2 - 6 } & B3 & 1.5 & 986 & - & - \\
\hline \multirow{2}{*}{ No.4 } & A4 & 3.1 & 1124 & - & - \\
\cline { 2 - 6 } & B4 & 1.4 & 1004 & - & - \\
\hline
\end{tabular}
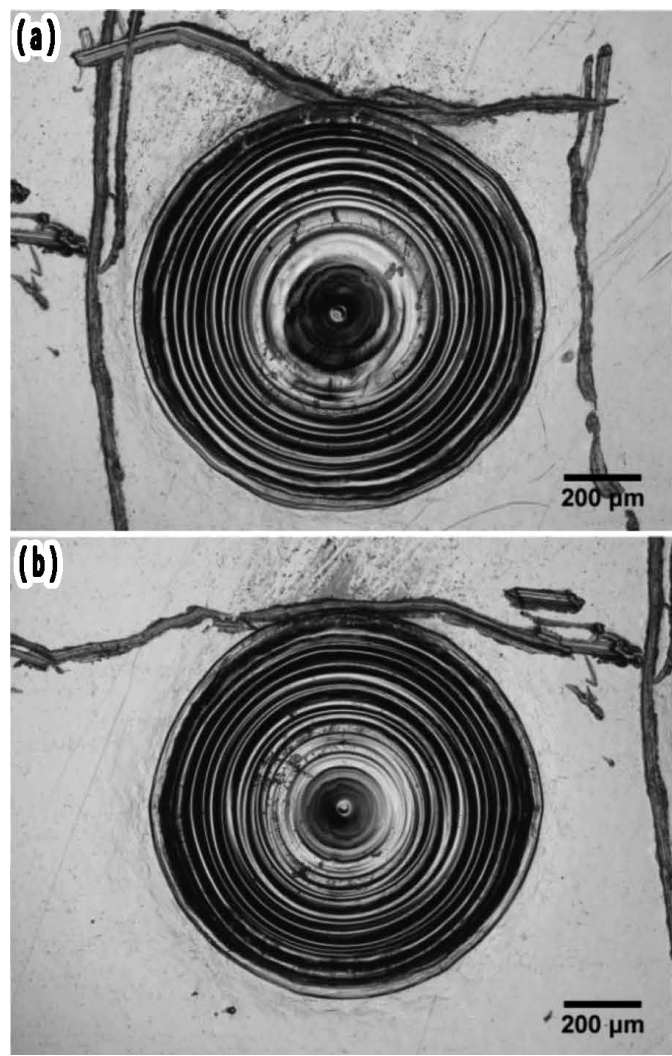

Figure 2: Welding spots: a) welding spot A1, corresponding to Figure 1a, b) welding spot B1, corresponding to Figure 1b
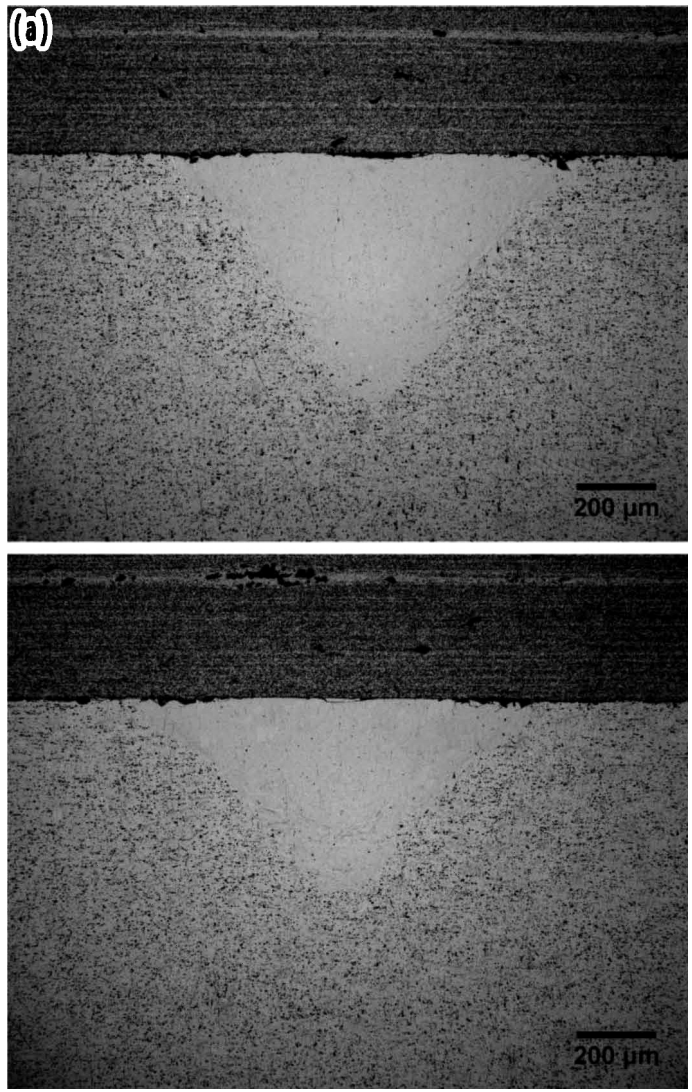

Figure 3: Cross-section of: a) welding spot A1, b) welding spot B1

Based on the results in Figures 1, 2 and 3, it can be found that the weld penetration and width of a welding spot are larger in the micro-zone where the content of IMCs is higher, which is consistent with the result of another tested group.

The statistical results for the IMCs, weld width and penetration are included in Table 3. The results indicate that the distribution of IMCs in the micro-zones may cause a size difference in the welding spots.

\subsection{Results of the EPMA}

To measure an element content of welding spots more accurately, 13 points were tested for each welding spot, as shown in Figure 4, and the results of the EPMA are shown in Figure 5.

Figure 5a shows the EPMA result for the third group of welding spots. Symbols $\mathbf{a}$ and $\bullet$, respectively, represent the contents of $\mathrm{Fe}$ and $\mathrm{Mn}$ of each tested point at the surface of welding spot A3. Symbols $\square$ and $\bigcirc$, respectively, represent the contents of $\mathrm{Fe}$ and $\mathrm{Mn}$ of each tested point at the surface of welding spot B3. The straight line and dotted straight line, respectively, represent the average value.

As shown in Figure 5a, the average contents of $\mathrm{Fe}$ and $\mathrm{Mn}$ of welding spot A3 are $0.824 \%$ of mass fractions and $0.235 \%$ of mass fractions, respectively. The average contents of $\mathrm{Fe}$ and $\mathrm{Mn}$ of welding spots B3 are 


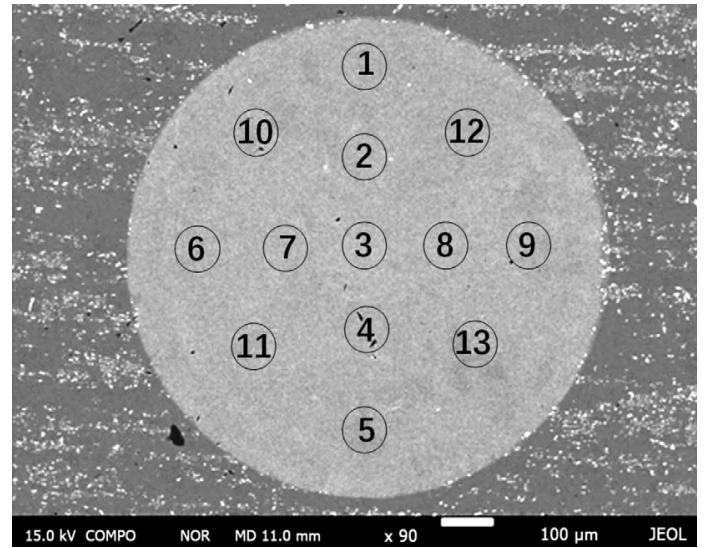

Figure 4: Schematic of the EPMA

$0.775 \%$ of mass fractions and $0.229 \%$ of mass fractions, respectively. Both the $\mathrm{Fe}$ and $\mathrm{Mn}$ contents at the surface of welding spot A3 are higher than those of welding spot B3.

Figure 5b shows the EPMA result for the fourth group of welding spots where a total of 6 points were tested. The average contents of Fe and $\mathrm{Mn}$ of welding spot A4 are $0.889 \%$ of mass fractions and $0.248 \%$ of mass fractions, respectively. The average contents of $\mathrm{Fe}$
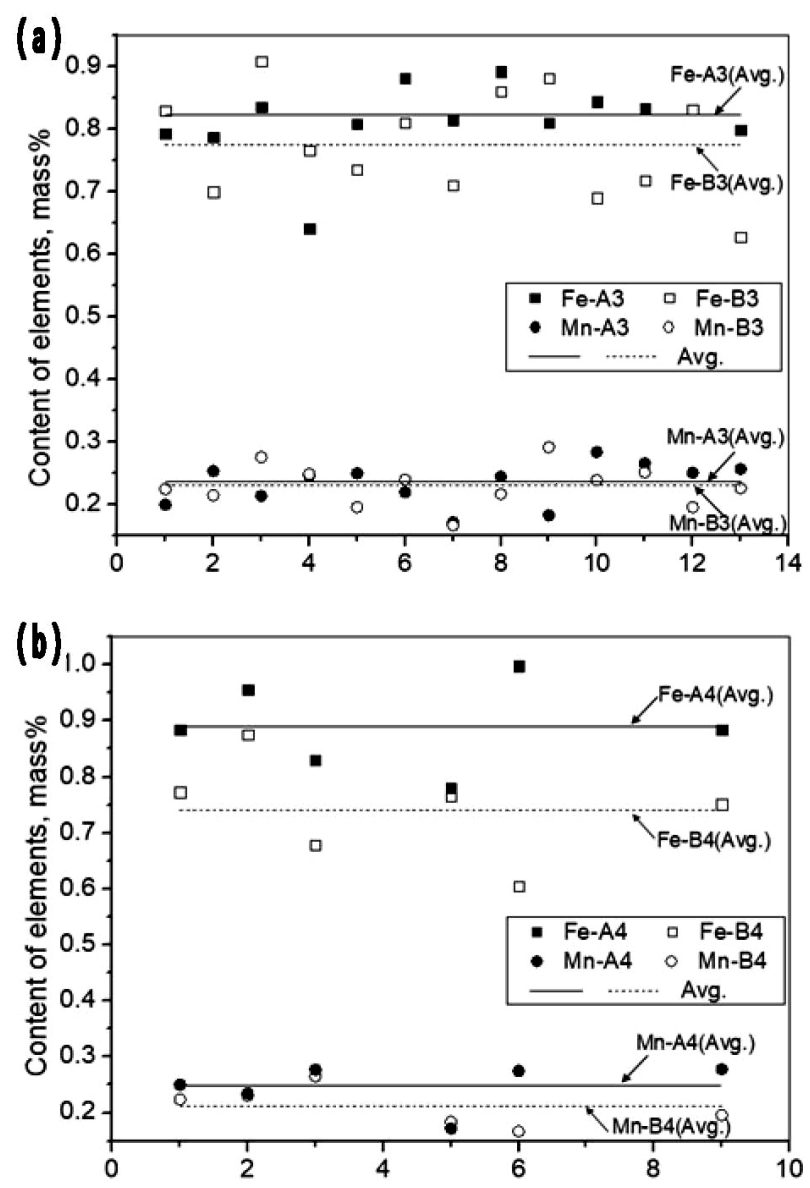

Figure 5: Results of the EPMA: a) No. 3, welding spots A3 and B3, b) No. 4, welding spots A4 and B4 and Mn of welding spot B4 are $0.741 \%$ of mass fractions and $0.211 \%$ of mass fractions, respectively. These results are consistent with the results from Figure 5a, that is, the contents of $\mathrm{Fe}$ and $\mathrm{Mn}$ at the surface of large-sized welding spots (A3 and A4) are higher than those of small-sized welding spots (B3 and B4).

Due to an insufficient flow of the melt and a very short solidification time of the weld pool during laser spot welding, there is insufficient time for the alloying elements in the welding spot to diffuse, resulting in a non-uniform distribution of elemental contents in each micro-zone.

\section{DISCUSSION}

\subsection{Discussion of the EPMA results}

The primary IMCs, such as $\mathrm{AlFe}, \mathrm{Al}(\mathrm{FeMn})$ and $\mathrm{Al}(\mathrm{FeMn}) \mathrm{Si}$, almost completely redissolve in the melt due to a very high temperature of the molten pool. The duration of laser spot welding is extremely short, and the metal melting and the solidification of the molten pool are completed within a few milliseconds. ${ }^{16}$ Thus, the main microstructure of a solid weld pool is a supersaturated solid solution. In a specific micro-zone, if the content of IMCs is high before the welding, the content of the alloying elements of the supersaturated solid solution in the weld pool is high as well.

According to the data from Table 3, it can be found that the aspect ratio (weld penetration divided by weld width) of the welding spots in this study is within the range of $0.5-0.6$, which is a typical heat-conduction welding (an aspect ratio $\leq 1.2$ ). ${ }^{17}$ In heat-conduction spot welding, the formation of a molten pool mainly depends on the heat conduction, and the flow of the melt in the weld pool is limited. Therefore, it is reasonable to obtain the IMCs content of the original sheet surface by measuring the element content at the surface of the welding spot.

The EMPA results for the welding spots are consistent enough with the statistical results of the pre-weld IMCs in the sheet surface. That is to say, at the microzones where the size of the welding spot is large, the content of IMCs is high before the welding and the contents of compositional elements $\mathrm{Fe}$ and $\mathrm{Mn}$ are also high after the welding.

\subsection{Analysis of the influencing factors}

It was reported that deep-penetration welding and heat-conduction welding may occur randomly during laser welding, resulting in a fluctuation of the weld penetration and width. D. Zhang et al. ${ }^{10,11}$ reported that the thermal focusing of lens changed the focal position during high-power $\mathrm{CO}_{2}$ laser welding, which caused a transition of the welding modes and an obvious fluctuation of the weld width and penetration. 
J. C. Wang et al. ${ }^{12,13}$ concluded that during the $\mathrm{Nd}$ :YAG laser welding, when the laser power density was close to the threshold of a keyhole formation, the laser energy absorbed by the workpiece fluctuated due to the fluctuation of the plasma itself and the laser absorption by the plasma. As a result, the keyhole could be unstable, leading to the instability of the welding process (two weld modes would appear randomly).

It was pointed out by A. Heider et al. ${ }^{14}$ that the melt ejection of the weld pool caused a loss of heat and collapse of the keyhole during the laser welding of copper alloys, resulting in a fluctuation of the weld width and penetration.

In the case of heat-conduction welding, there are no plasma or keyhole, ${ }^{12}$ and the melt ejection is very limited. Furthermore, the thermal-focusing effect does not occur due to the extremely short duration (which is usually a few milliseconds) of the spot-welding process. Therefore, the problem of the present study cannot be reasonably explained by the above studies.

The $\mathrm{CO}_{2}$ laser spot welding of aluminum alloy was discussed by W. Tao et al. ${ }^{15}$ When the laser power was close to the threshold, the size of welding spots fluctuated greatly. This was due to the fact that the surface roughness, impurities and defects were different across the workpiece surface, resulting in a difference in the laser absorption by various zones of the workpiece surface.

Some scholars ${ }^{16}$ studied the Nd:YAG laser spot welding of the 1100 aluminum alloy and found an abnormal phenomenon whereby the penetration depth of some welding spots with black stains on the surface dropped with an increased peak power. This could have been caused by the stains and dust on the surface of the aluminum sheet, impurities in the shielding gas or aluminum sheet.

In this study, the sample was ground and polished, and then wiped with alcohol before the welding. Therefore, the effect of surface inconsistency or stains on the welding can be eliminated. In addition, there were no black stains on the welding-spot surface, so the effect of impurities in the shielding gas or aluminum sheet on the welding can also be excluded.

In the case of heat-conduction welding, the laser energy absorbed by the surface of a metal is converted into heat energy, which causes a rise in the temperature of the metal surface and metal melt. Then, the heat energy transfers to the inside of the metal through heat conduction to form a molten pool.

In ${ }^{18}$ it is noted that the actual laser absorptivity of a metal surface consists of two parts. One is the intrinsic absorptivity depending on the optical properties of the metal, and the other is the extrinsic absorptivity depending on the optical properties of the metal surface. With a fixed laser wavelength, the intrinsic absorptivity of metal is mainly related to the electrical conductivity of metal. The lower the conductivity of metal, the higher is the laser absorptivity of metal. The extrinsic absorptivity is dependent on the roughness, defects, impurities, oxide layers or coating of the metal surface.

In this study, the oxide layer and defects of the sample surface were removed and the surface had a uniform roughness after grinding and polishing. The surface optical properties of both micro-zones A and B were identical, resulting in the same extrinsic absorptivity. Therefore, the actual absorptivity of the two kinds of welding zones depends on their intrinsic absorptivity.

The electrical conductivity of the IMCs of the Al-Fe alloy, including $\mathrm{AlFe}, \mathrm{Al}(\mathrm{FeMn})$ and $\mathrm{Al}(\mathrm{FeMnSi})$, is much lower than that of pure aluminum and pure iron. ${ }^{19}$ Since the intrinsic absorptivity is inversely proportional to the electrical conductivity of a material, it can be inferred that the laser absorptivity of the IMCs, such as $\mathrm{AlFe}, \mathrm{Al}(\mathrm{FeMn})$ and $\mathrm{Al}(\mathrm{FeMn}) \mathrm{Si}$, is probably much higher than that of pure aluminum and its alloys, based on laser-absorptivity equations given by the literature. . $^{18,20}$

The composition of a metal can be simply divided into the matrix and IMCs. For the same sheet, the solid solubility in the matrix of each zone within a limited range can be approximately regarded as the same. Thus, the difference in the micro-zones can be distinguished by the difference in the contents of the IMCs.

The laser absorption of a micro-zone is equal to the sum of the laser absorption of the matrix and of the IMCs. The laser absorptivity of IMCs is much higher than that of the matrix, so the laser absorptivity increases with an increase in the area fraction of IMCs.

Therefore, the intrinsic absorptivity of a micro-zone with a high content of IMCs may be relatively higher, resulting in high laser energy absorbed by the microzone. ${ }^{2}$ That is to say, even with the same surface characteristics, the laser absorptivity of each micro-zone on the same sheet can be different, and the micro-zone with a high content of IMCs may have a higher laser absorptivity.

The laser absorbance increases drastically once the metal has melted. However, the difference in the laser absorptivity within any set of metals is not obvious in the liquid state. ${ }^{21}$ Therefore, the effect of laser absorptivity at room temperature on laser welding is significant.

The reason why the laser absorbance by an aluminum alloy is very low is that the density of free electrons, which are easy to interact with the photons of a laser beam to deflect the energy, is high on the surface of a solid aluminum alloy. ${ }^{4,8}$ The free-electron density of IMCs is lower than that of the matrix. ${ }^{22}$ Therefore, an increase in the amount of IMCs in the surface of an aluminum alloy (which means that the free-electron concentration at the surface decreases simultaneously) is conducive to the increase in the laser absorptivity.

Compared with the matrix, the thermal conductivity of the IMCs is lower due to a lower electrical conductivity, so the heat transfer of the IMCs is slower. An increase in the IMC content causes a lower heat transfer 
from the welding zone to the surrounding material, thereby allowing more heat energy to be retained in the welding zone, which is advantageous for the formation of a larger weld pool.

Based on the above, it can be established that the laser absorptivity of micro-zone A with a higher content of IMCs is much higher than that of micro-zone B. As a result, micro-zone A can obtain more laser energy and more heat input than micro-zone $\mathrm{B}$ under the same welding parameters, thus obtaining a larger weld pool.

\section{CONCLUSIONS}

During the laser spot welding of an Al-0.85Fe alloy sheet, a size difference in welding spots occurs even under the same surface condition and the same welding parameters. Compared with other micro-zones with a lower content of IMCs, the micro-zone at the sheet surface with a high content of IMCs easily develops a larger weld pool. The results show that the difference in the size of welding spots is related to the non-uniform distribution of IMCs in the micro-zones on the sheet surface. The main reason is that the laser absorptivity of IMCs is probably higher than that of the matrix, which leads to a more significant influence on laser welding.

\section{Acknowledgement}

This project was funded by the Priority Academic Program Development of Jiangsu Higher Education Institutions (PAPD).

\section{REFERENCES}

${ }^{1}$ Y. Birol, Interannealing twin-roll cast Al-Fe-Si strips without homogenization, Scripta Mater., 61 (2009), 185-188, doi:10.1016/ j.scriptamat.2009.03.031

${ }^{2}$ P. Z. Zhao, Y. F. Pan, T. Jiang, X. J. Shi, Q. Zhang, Effect of intermetallic compound content on the laser welding performance of Al-Fe alloy sheets, Mater. Sci. Forum, 794-796 (2014), 401-406, doi:10.4028/ www.scientific.net/MSF.794-796.401

${ }^{3}$ F. Andreatta, A. Lanzutti, L. Fedrizzi, Corrosion behaviour of AA8xxx aluminium fins in heat exchangers, Surf. Interface Anal., 48 (2016) 8, 789-797, doi:10.1002/sia.5961

${ }^{4}$ H. Zhao, D. R. White, T. DebRoy, Current issues and problems in laser welding of automotive aluminium alloys, Int. Mater. Rev., 44 (1999) 6, 238-266, doi:10.1179/095066099101528298

${ }^{5}$ J. Zhou, H. L. Tsai, Effects of electromagnetic force on melt flow and porosity prevention in pulsed laser keyhole welding, Int. J. Heat Mass Transfer, 50 (2007), 2217-2235, doi:10.1016/j.ijheatmasstransfer.2006.10.040
${ }^{6}$ X. J. Cao, W. Wallace, C. Poon, J. P. Immarigeon, Research and progress in laser welding of wrought aluminum alloys. I. Laser welding processes, Mater. Manuf. Processes, 18 (2003) 1, 1-22, doi:10.1081/AMP-120017586

${ }^{7}$ B. Lenczowski, New lightweight alloys for welded aircraft structure, http://icas.org/ICAS_ARCHIVE/ICAS2002/PAPERS/4101.PDF, 2002

${ }^{8}$ C. A. Huntington, T. W. Eagar, Laser welding of aluminum and aluminum alloys, Welding J., 62 (1983) 4, 105s-107s, https://app.aws.org/wj/supplement/WJ_1983_04_s105.pdf

${ }^{9}$ H. Sakamoto, K. Shibata, F. Dausinger, Effect of alloying elements on weld properties in $\mathrm{CO}_{2}$ laser welding of aluminium alloys, Weld. Int., 17 (2003) 7, 509-513, doi:10.1533/wint.2003.3137

${ }^{10}$ X. D. Zhang, W. Z. Chen, J. L. Ren, Influence of thermal focusing on mode transition and process stability in laser welding, J. Tsinghua Uni. (Sci. Tech.), 37 (1997) 8, 99-102

${ }^{11}$ X. D. Zhang, W. Z. Chen, J. L. Ren, G. Q. Huang, H. J. Zhang, Laser welding mode transition and influence of thermal focusing on mode transition, Proc. SPIE, 2888 (1996), 306-315, doi:10.1117/ 12.253136

${ }^{12}$ J. C. Wang, J. Y. Shen, X. Z. Wang, Effects of process factors upon laser welding instability for titanium alloys, Weld. Join., (2000) 9 , 17-19

${ }^{13}$ J. C. Wang, X. Z. Wang, J. Y. Shen, Calculative pattern of laser welding stability for titanium alloys, Trans. China Weld. Inst., 21 (2000) 4, 13-16

${ }^{14}$ A. Tao, P. Stritt, A. Hess, R. Weber, T. Graf, Process stabilization at welding copper by laser power modulation, Phys. Procedia, 12 (2011), 81-87, doi:10.1016/j.phpro.2011.03.011

${ }^{15}$ W. Tao, Y. B. Chen, L. Q. Li, L. Wu, Process characteristic of laser spot welding for aluminum alloy, Infrar. Laser Eng., 40 (2011) 4 , 659-663

${ }^{16}$ R. Hajavifard, M. Motahari, H. Özden, H. Miyanaji, S. Kafashi, The effects of pulse shaping variation in laser spot welding of aluminum, Procedia Manuf., 5 (2016), 232-247, doi:10.1016/j.promfg. 2016.08.021

${ }^{17}$ K. Richter, G. Bostanjoglo, R. Dommaschk, R. Mayrhofer, D. Paethe, H. Weber, Comparative study on aluminum and steel welding with cw and repetitively Q-switched Nd:YAG lasers, Proc. SPIE, 2789 (1996), 12-20, doi:10.1117/12.251175

${ }^{18}$ T. C. Zuo, Laser materials processing of high strength aluminum alloy, National Defense Industry Press, Beijing 2008

${ }^{19}$ R. Wang, Physical properties of metal materials (revised edition), Metallurgical Industry Press, Beijing 1993, 48-49

${ }^{20}$ R. Indhu, V. Vivek, L. Sarathkumar, A. Bharatish, S. Soundarapandian, Overview of laser absorptivity measurement techniques for material processing, Springer Nature, 2018, doi:10.1007/s40516018-0075-1

${ }^{21}$ B. C. Kim, T. H. Kim, J. S. Kim, K. B. Kim, H. Y. Lee, Investigation on the effect of laser pulse shape during Nd:YAG laser microwelding of thin Al sheet by numerical simulation, Metall. Mater. Trans. A, 33A (2002) 5, 1449-1459, doi:10.1007/s11661-002-0068-7

${ }^{22}$ W. Deng, L. Y. Xiong, M. Z. Cao, S. H. Wang, J. T. Guo, Q. W. Long, Free electron densities and microdefects in aluminide intermetallic compounds and their bond composition, Sci. China (Ser. A), 30 (2000) 10, 940-945 